\title{
Evolutionary Trends in Bolivina From Maastrichtian to Eocene, Nigeria
}

\author{
Enam O. Obiosio ${ }^{1}$ \\ ${ }^{1}$ Department of Geology, Ahmadu Bello University, Zaria, Nigeria \\ Correspondence: Enam O. Obiosio, Department of Geology, Ahmadu Bello University, Zaria, Nigeria. E-mail: \\ enamob@yahoo.com, eoobiosio@abu.edu.ng
}

Received: February 26, 2013 Accepted: March 14, 2013 Online Published: March 28, 2013

doi:10.5539/esr.v2n2p128

URL: http://dx.doi.org/10.5539/esr.v2n2p128

\begin{abstract}
SEM study of Maastrichtian to Eocene bolivinids shows evolutionary trends of biocharacters in recognized lineage leading from Afrobolivina afra to Bolivina ignara. The foremost trends is the reduction in size of the Afrobolivina afra to Bolivina ignara. Other trends are: increased flare of chambers (B. ignara), development of coarser and more widely set pores (B. striatella, B. ottaensis and B. ignara), more closely set pores (Afrobolivina afra and $B$. africana), development of costae and sutural lobes that became less prominent from Afrobolivina afra to B. ignara. Two phylogenetic lineages are proposed based on evolutionary trends that have allowed the linkage of related forms: Afrobolivina afra, Bolivina africana, B. striatella and B. ottaensis, and Afrobolivina afra, B. africana and B. ignara.
\end{abstract}

Keywords: biocharacter, phylogeny, bolivinids, pores, sutural lobes, evolutionary trends, SEM micrographs

\section{Introduction}

Detailed research on Bolivina was restricted to Europe and America where various authors have investigated the taxonomy, phylogeny and stratigraphic distribution of species belonging to this genus. Relatively little is known about the group from other parts of the world.

Studies of evolutionary trends of morphological features in Bolivina groups dates back to Cushman and Todd (1941) assessment of biocharacters for stratigraphic purpose. Cicha and Zapetalova (1964) analyses of the bolivinids of western carpathians allowed the synthesis of their phylogenetic development on the basis of their biocharacters. Lindenberg (1965) utilized the evolutionary trends of several biocharacters for stratigraphy and palaeoenvironment. Similar study by Hoffman (1967) in Germany revealed evolutionary trends in Bolivina morpho character and its application to stratigraphy. In all of these studies, evolutionary trends investigated involved, increase of test, alteration of width and thickness of test, longitudinal costae, and pore densities and distribution over the test.

Particular attention has not been paid to the study of bolivinid evolutionary trend in Nigeria except for a study carried out by Ogbe (1980), on Afrobolivina afra Reyment, in relation to morphological variations and linking it to evolutionary trends. The bolivinid group in Nigeria is represented in the Maastrichtian to Pliocene of southern Nigeria sedimentary basins by over 40 species (Reyment, 1959; Fayose 1969; Ogbe, 1980; Petters, 1982; Obiosio, 2011).

The Objective of the paper is to qualitatively assess the morphological test characters of forms revealed by SEM micrographs that show clear relationships that could be linked to evolutionary development, and suggest a possible phylogeny. 


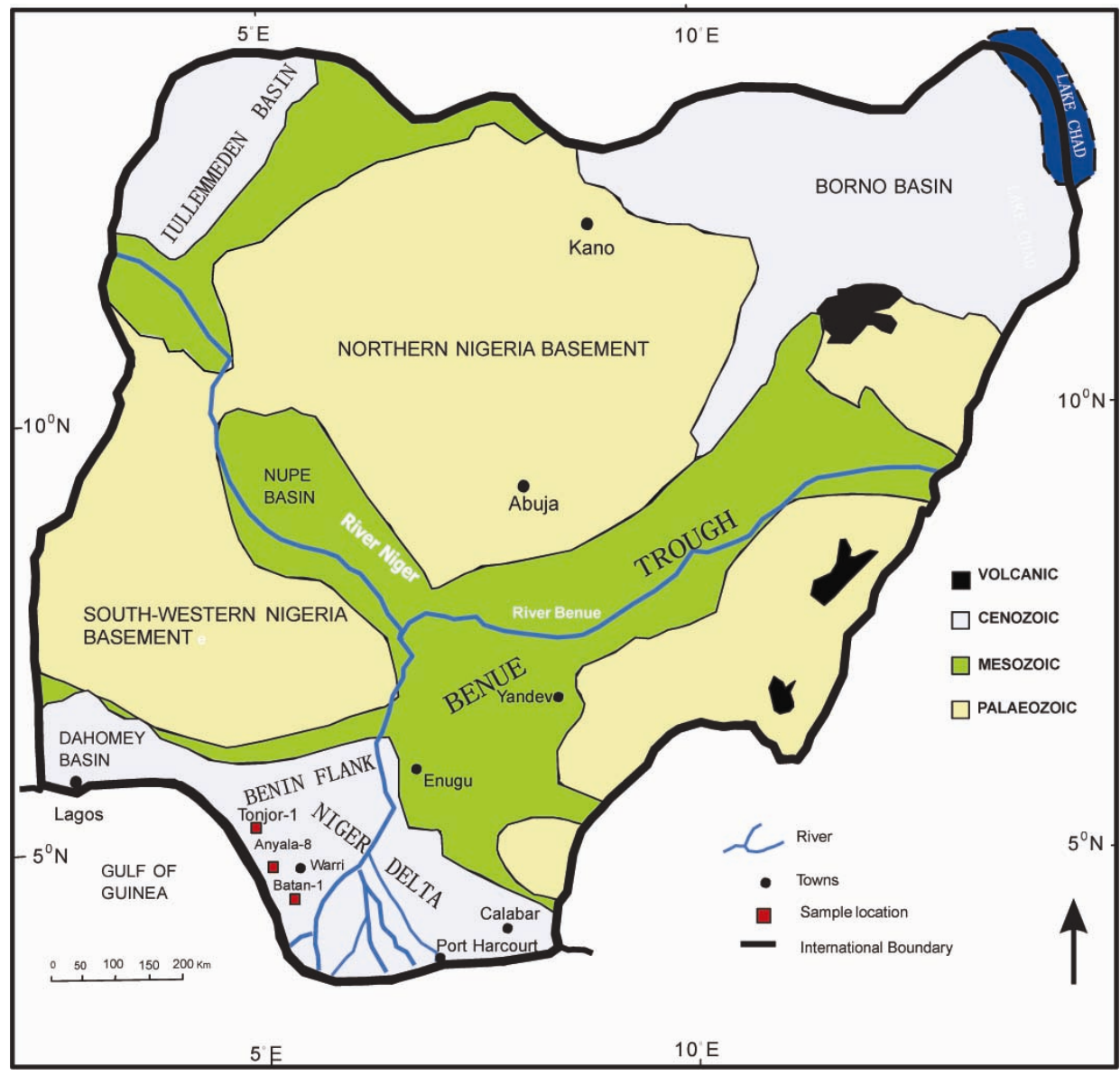

Figure 1. Geological map of Nigeria showing sample locations (Modified from Geological Survey of Nigeria, 1974)

\section{Systematic Palaeontology}

The present account follows the arrangement of families and genera given by Loeblich and Tappan (1987). Synonymies are not provided since they are indicated in published works.

Order Foraminiferida Eichwald 1830

Family: Bolivinitidae Cushman 1927

Genus: Bolivina d'Orbigny 1839

\section{1) Afrobolivina afra (Reyment, 1959, Figure 2a)}

Remarks: Represented by a large bolivinid with a cylindrical, gradually flaring test, acute periphery, well developed finger-like processes at the base of chambers and longitudinal costae that passes in between, finger-like processes; the test is coarsely porous. Maximum test length is $0.46 \mathrm{~mm}$ and width is $0.17 \mathrm{~mm}$. Length/width ratio is 2.7 .

Occurrence: Common in the Maastrichtian part of Nkporo shale in the eastern Dahomey basin. This species also occurs in the Campanian-Maastrichtian of Angola, Gabon, Cameroon, Nigeria, Cote d'Ivoire and Senegal (Castelain et al., 1962). This species was not found in the Palaeocene (Petters, 1982).

2) Bolivina africana (Graham, De Klasz, \& Rerat, 1965, Figure 2b)

Remarks: The test is club-shaped, medium size, gradually broadening and elongate; maximum chamber width occurs along the apertural ends; finger-like processes are almost absolescent at the first few chambers but slightly visible in the last three pairs of chambers; costae are prominent and continuous from the proloculus to the last pair of chambers. The test is pierce by pores that are not as dense as in Afrobolivina afra. Maximum length of test is $0.45 \mathrm{~mm}$ and width is $0.15 \mathrm{~mm}$. Length/width ratio is 3.0 . 
Occurrence: It occurs in the Palaeocene of Niger Delta (Petters, 1982). Originally described from the Palaeocene of Gabon (Graham et al., 1965).

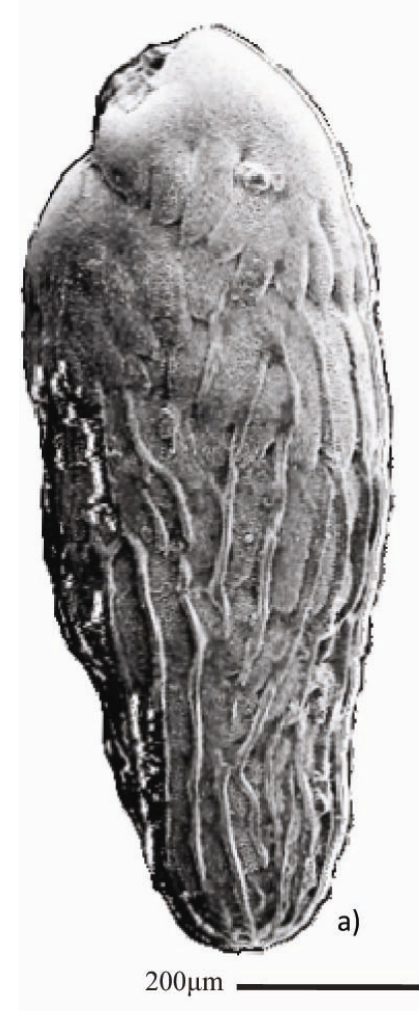

Afrobolivina afra

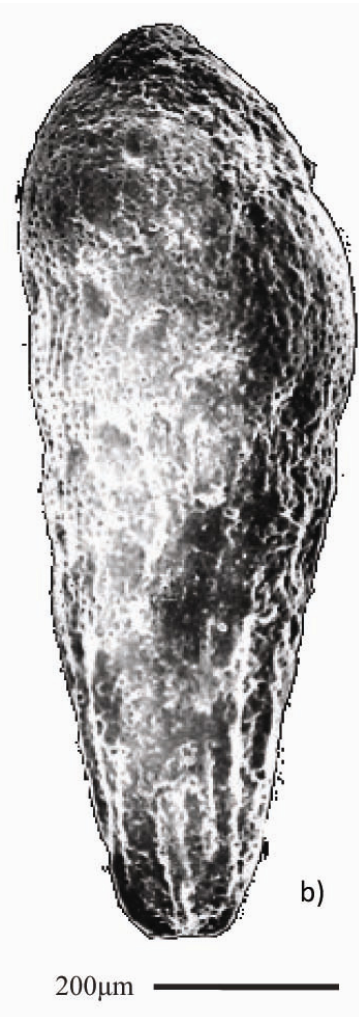

Bolivina africana

Figure 2. Test showing sutural lobes, pores and costae

3) Bolivina striatella (Cushman, 1925, Figure 3a)

Remarks: Test is bolivinid elongate, periphery acute, keeled; wall finely punctuate; ornamentation of wide costae, parallel and sometimes anastomosing, becoming obsolescent in the last few chambers. Maximum test length is $0.32 \mathrm{~mm}$ and width is $0.12 \mathrm{~mm}$. Length/width ratio is 2.7 .

Occurrence: Occurs in the Niger Delta. Also known to occur in the Gulf of Guinea (Brun et al., 1984).

4) Bolivina ignara (Cushman \& Stone, 1949, Figure 3b)

Remarks: Test elongate, gradually broadening with pronounced flare; periphery subacute to slightly rounded; last pair of chambers somewhat high and subquadrate. Maximum length is $0.29 \mathrm{~mm}$ and width is $0.15 \mathrm{~mm}$. Length/width ratio is 1.9 .

Occurrence: Occurs in the Eocene of Niger Delta, Nigeria. This species has been described from the Eocene of Peru (Cushman \& Stone, 1949). 


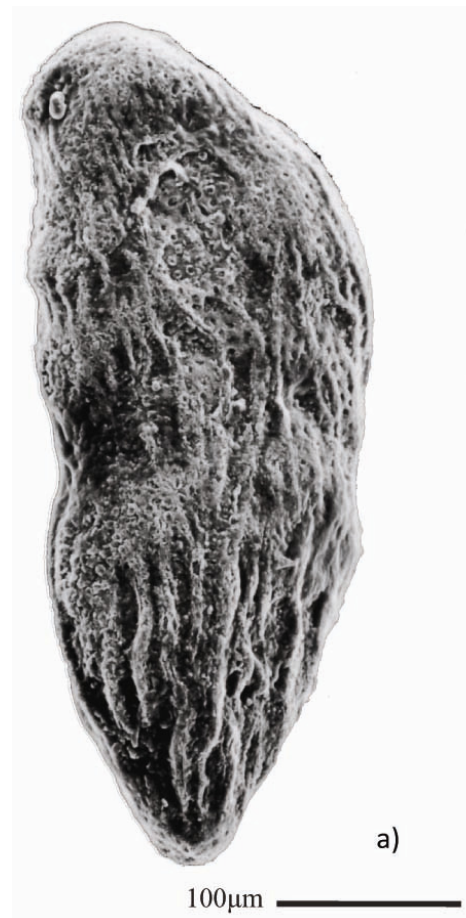

Bolivina striatella

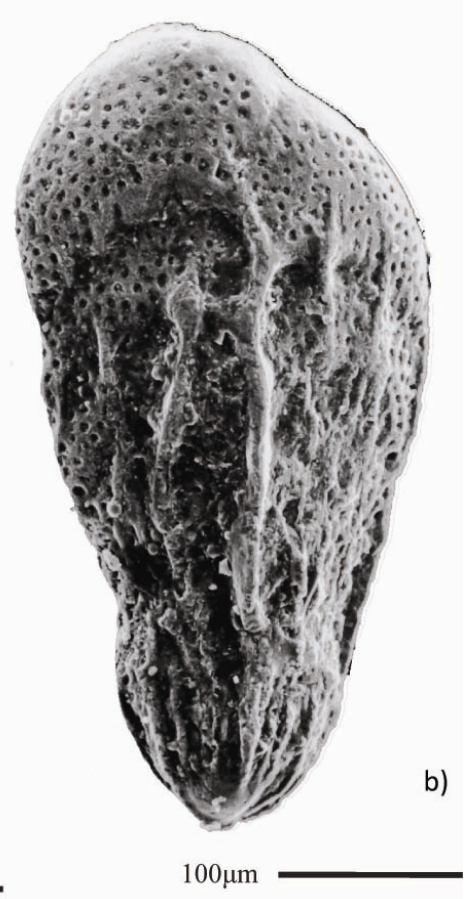

Bolivina ignara

Figure 3. Test showing sutural lobes, pores, costae and keel

5) Bolivina ottaensis (Reyment, 1959, Figure 4)

Remarks: Test cylindrical, outline irregular; Chambers indistinct except for the last two pairs; ornamented with costae that may be anastomosing; chamber overlap obvious in the last pairs of chambers. Maximum length is $0.30 \mathrm{~mm}$ and width is $0.14 \mathrm{~mm}$. Length/width ratio is 2.1 .

Occurrence: Occurs in Eocene of Southwestern Nigeria and Niger Delta.

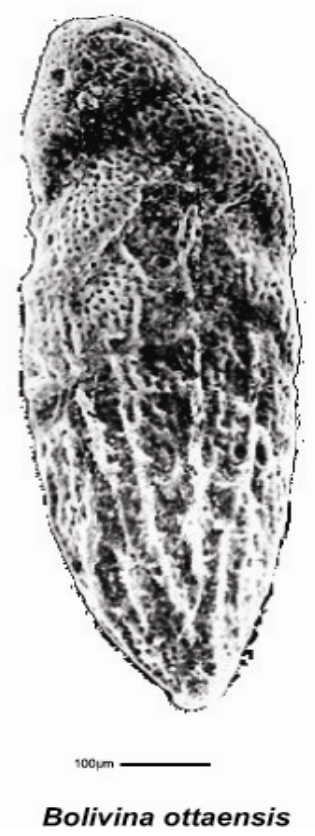

Figure 4. Test showing sutural lobes, pores, costae and keel 


\section{Evolution and Phylogeny}

Evolutionary trends in morphological features which allowed the linkage of related forms are found only in a few cases. Scanning electron micrograph study of surface morphology is presented (Figures 2-4). Bolivinids that are considered as part of lineages exhibiting trends are Afrobolivina afra, Bolivina africana, Bolivina striatella, Bolivina ottaensis and Bolivina ignara. The surface morphology reveals that the Bolivina species show trends affecting shape, size, pore characteristics and ornamentation.

The shape of the test shows modification towards an acute peripheral margin. In mid - section there is a trend from a round section in the most primitive form (Afrobolivina afra) through a somewhat ovoid or club-like section in Bolivina africana, to a slightly conical section in the Bolivina striatella and Bolivina ottaensis lineage and to a rhombic section in a separate phylogenetic branch leading to Bolivina ignara. Also, the most rounded margin is developed in Afrobolivina afra followed by sub-rounded in B. africana acute in Bolivina striatella and Bolivina ottaensis and sub-acute in Bolivina ignara. The development of the most acute margins in $B$. striatella and $B$. ottaensis extends as a keel to half of the test length. The development of a marginal keel and rhombic section are features which remove $B$. ignara from the $B$. striatella and B.ottaensis lineage to a separate phylogenetic branch (Figure 5).

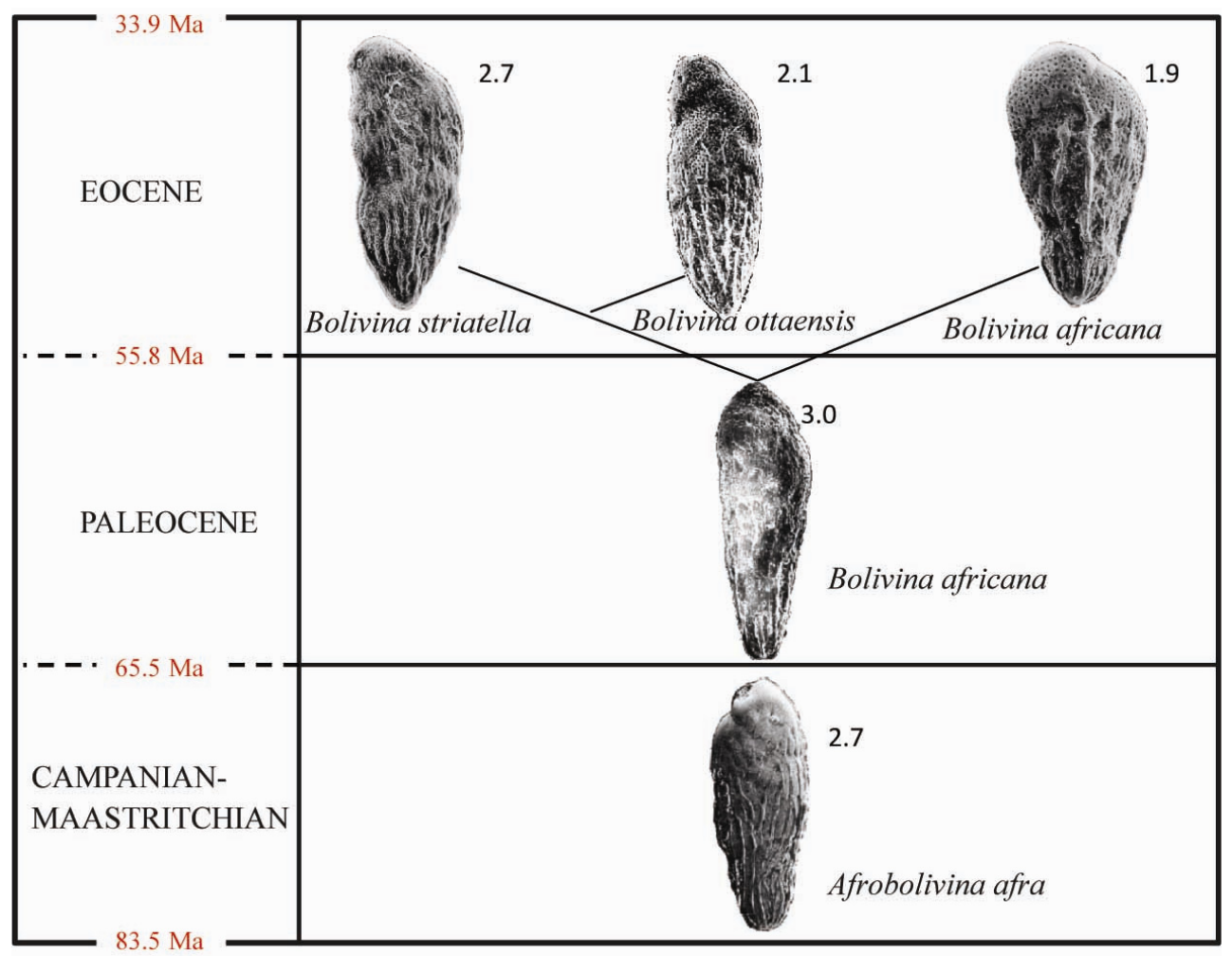

Figure 5. Phylogenetic relationship suggested for selected Bolivina Species

From the earliest form, Afrobolivina afra, to the youngest, Bolivina striatella, B. ottaensis and B. ignara, there is a general decrease in absolute length of the test from $0.46 \mathrm{~mm}$ to $0.29 \mathrm{~mm}$. Bolivina ignara appears to be in an evolutionary line with absolute test length of $0.29 \mathrm{~mm}$ compared to $0.32 \mathrm{~mm}$ in Bolivina striatella and $0.30 \mathrm{~mm}$ in Bolivina ottaensis phylogenetic line. The progressive decrease in width of the test is shown by a general decrease in length/width ratio from 2.7 in the earliest species Afrobolivina afra to 3.0 in B.africana to 2.7 in $B$. striatella and 2.1 in B. ottaensis and 1.9 in B. ignara (Figure 5). Dodson and Reyment (1980) also noted size reduction between these bolivinid species.

Pores coarsen and become widely set in Bolivina ignara. The Late Cretaceous Afrobolivina afra has fine, rounded and densely spaced pores but they change to coarse, sunken and somewhat more widely spaced features in the Paleocene Bolivina africana. There is a divergence into two phylogenetic branch in the Eocene: i) the 
Bolivina striatella and $B$. ottaensis lineage which retains the pore characteristics of $B$. africana; and ii) the $B$. ignara lineage in which the pores are coarse and widely spaced.

As regards ornamentation, the costae and sutural lobes are less prominent in Bolivina africana than in Afrobolivina afra. Sutural lobes are present in all the chambers of Afrobolivina afra become restricted to the last two pairs of chambers in B. africana and occur only on the last pair of chambers in Bolivina ignara. These characters can be dependent on environmental influences but the present material suggests they have stratigraphic significance.

\section{Conclusion}

Afrobolivina afra, Bolivina africana and Bolivina ignara are thought to form a phylogenetic lineage, with $B$. africana also giving rise to Bolivina striatella and Bolivina ottaensis to form another lineage. There is a trend from a round section in Afrobolivina afra through a somewhat ovoid or club-shape section in B. africana to a slightly conical section is B. striatella and B. ottaensis and to a rhombic section in B. ignara.

The evolution of pores, show two trends: they coarsen in B. striatella, B. ottaensis and B. ignara and become fine and densely perforated in Afrobolivina afra and less so in B. africana.

The costae and sutural lobes become progressively less prominent from Afrobolivina afra to Bolivina ignara. The occurrence of these features does suggest they have stratigraphic significance.

\section{Acknowledgement}

The author express thanks to Professor Wolfgang Kuhnt of the University of Kiel, Germany, for providing the facility for producing scanning electron micrographs, and thanks are due to Dr Anne Holbourn for assisting with the taxonomy of Bolivinids. MacArthur Foundation provided financial support.

\section{References}

Brun, L., Chierici, M. A. A., \& Meijer, M. (1984). Evolution and morphological variations of the principal species of Bolivinitidae in the Tertiary of the Gulf of Guinea. Géologie Méditerranéenne, XI, 13-57.

Castelain, J., Faulkner, J. S., De Klasz, I., Meijer, M., \& Rerat, D. (1962). Répartition stratigraphique d' Afrobolivina afra REYMENT dans quelques basins côtiers de L'Afrique occidentale. Revue de Micropaléontologie, 5, 54-58.

Cicha, I., \& Zapetalova, I. (1964). Die biostratigraphiche bedeutung der gattung Bolivina (Foraminifera Protozoa) in Miozän der Westkarpaten. Inst «Lucas Mallada», Cursillos Y Conference, Proceeding, 9, 119-121.

Cushman, J. A. (1925). Some Textulariidae from the Miocene of California. Contribution Cushman Laboratory for Foraminiferal Research, 1, 29-35.

Cushman, J. A. (1927). American Upper Cretaceous Species of Bolivina and related species. Cushman Laboratory for foraminiferal Research Contribution, 2, 85-91.

Cushman, J. A., \& Stone, B. (1949). Foraminifera from the Eocene, Chacra Formation of Peru. Cushman Laboratory for Foraminiferal Research Contribution, 25, 49-58.

Cushman, J. A., \& Todd, R. (1941). Statistical studies of some Bolivinas. Cushman Laboratory for Foraminiferal Research Contribution, 17(1), 29-33.

Dodson, M. M., \& Reyment, R. A. (1980). Analysis of the extinction of the Late Cretaceous foraminifer Afrobolivina afra. Cretaceous Research, 1, 143-164. http://dx.doi.org/10.1016/0195-6671(80)90022-1

d'Orbigny, A. D. (1839). Foraminifères. In R. de la Sagra (ed.). Histoire physique. politique et naturelle de l'île de Cuba. Paris, A. Bertrand, 8, 1-224.

Eichwald, C. E. von. (1830). Zoologia specialis. Vilnae: D. E. Eichwaldus, 2, 1-323.

Fayose, E. A. (1969). A note on the taxonomic status of the genus Afrobolivina Reyment 1959. Research Contribution Cushman Foundation for Foraminiferal, 20, 145-146.

Geological Survey of Nigeria. (1974). Geological map of Nigeria. Scale 1: 2,000,000. Geological Survey Division, Federal Ministry of Mines and Power, Nigeria.

Graham, J. J., de Klasz, I., \& Rerat, D. (1965). Quelques importants foraminifères du Tertiaire du Gabon (Afrique Équatoriale). Revue de Micropaléontologie, 8(2), 71-84.

Hoffmann, C. W. (1967). Untersuchungen an der gattung Bolivina (Foraminifera) in Oligozän un Miozan der Ostbayrichen Molasse. Geologica Bavarica, 57, 121-204. 
Lindenberg, H. G. (1965). Die Bolivinen (Foram.) der Häringen Schichten. Mikropaläontologische untersuchungen in Alttertiär des Unterinntal Gebietes, Bollettino della Società Paleontologica italiana, 4, 64-160.

Loeblich, A. R. Jr., \& Tappan, H. (1987). Foraminiferal genera and their classification (p. 2047). New York: Van Nostrand Reinhold Company.

Obiosio, E. O. (2011). Biostratigraphy Phylogeny and Palaeoecology of the Eocene to Pliocene foraminifers Bolivina and Brizalina from the western Niger Delta, Nigeria. Unpublished PhD Dissertation, Ahmadu Bello University, Zaria, Nigeria.

Ogbe, F. G. A. (1980). Bolivina afra (REYMENT) emended. Revista Espaňola de Micropaleontología, 12, 263-266.

Petters, S. W. (1982). Central West African Cretaceous - Tertiary benthic Foraminifera and stratigraphy, Paleontographica A, 179, 1-104.

Reyment, R. A. (1959). The foraminiferal genera Afrobolivina gen. nov. and Bolivina in the Upper Cretaceous and Lower Tertiary of West Africa. Stockholm Contributions in Geology, 3, 1-57. 